\title{
FOR THE RIGHTS OF "NOBODIES": THE GLOBALISING TENSION BETWEEN HUMAN RIGHTS AND DEMOCRACY
}

\author{
Koji Teraya *
}

\begin{abstract}
In this article, the author suggests that democracy should not be accepted as a wholly positive ideal without question, examining in particular the assumption that democracy always ensures the protection of human rights. To highlight this concern, the author focuses on the creation of "Nobodies"-individuals within democratic states that are expelled and, as a result, are deprived of human rights, including those who are deprived of nationality and those who are expelled by the operation of law, concluding that blind efforts to reduce "democratic deficit" may in fact aggravate the violation of Nobodies' rights.
\end{abstract}

\section{INTRODUCTION}

Democratic governance has long been regarded by international lawyers as a desirable object, especially since the 1990s. ${ }^{1}$ Regardless of their variety of emphases, the basic presumption seems that democratic governance is inherently desirable and its coordination with international law matters next. The Call for Papers of this symposium seems to take this position, saying that a "number of international lawyers are now addressing whether international law and institutions are 'democratic"'. ${ }^{2}$ Based on the presumption that democracy is universally good, the current discourse regards democratic deficit as a serious concern. While the undemocratic character of international law has long been recognised, fervent support for democracy makes its limited success at the international level prominent.

The influence of democracy is remarkable in the international sphere, but values not protected by democracy should also deserve attention. To evaluate democratic governance, the concept of human

\footnotetext{
* Associate Professor, Graduate School for Law and Politics, University of Tokyo. Warm thanks to the participants in the Conference for their helpful comments and Mr Jack Wass for his careful proofreading. All errors are naturally to be attributed to me.

1 Thomas Franck "The Emerging Right to Democratic Governance" (1992) 86 Am J Int'l L 46.

2 See also José E Alvarez "Introducing the Themes" in this volume.
} 
rights is the most suitable key. Whether being used in an internal or international context, the core meaning of democracy remains rule by the demos, the many, while human rights have a unique role when they are claimed by minorities, especially in the sense of Ronald Dworkin's famous expression, "political trumps". ${ }^{3}$ Are the rights of minorities protected enough in democratic states? Is democracy so reliable? If not, why and how are the rights of minorities so easily marginalised? To what extent is human rights violation inherent in democratic governance? Commentators frequently examine the celebrated claim that "democratic states never fight each other", but it is much more dubious whether democratic states are innocent of the violation of human rights.

Moreover, the tension between the many and minorities covers many more people than before in the age of globalisation. Minorities can include ethnic groups, foreigners, stateless persons, refugees and those who are regarded as "criminals", all at the same time. Attention should also be paid to numerous people in poor countries that are in substance "minorities", even though they make up the majority of the world. This paper calls the above persons "Nobodies" ${ }^{4}$ in the sense that little attention is paid to them, as if they did not exist. As will be shown, they are not the same as minorities stricto senso such as prescribed in Article 27 of the International Covenant on Civil and Political Rights (ICCPR), because the process of expelling Nobodies shows that the problem is not limited to the position existing within states but is deeply structured in the global system. In addition, Nobodies are not just minorities in a numerical sense. Their expulsion takes place within an epistemological framework. These features make the issue different from the traditional tension between the many and the minorities; examining the issue from the perspective of Nobodies will show the contemporary problems of democracy.

This paper aims to evaluate democratic values in terms of the globalising tension between human rights and democracy. In fact, human rights are only one important perspective from which to assess democracy, because democracy itself has been discussed since ancient times before the idea of human rights was born. However, the modern discourse closely relates democracy with human rights. It wrongfully treats these two as if they were bound together. This relationship thus assures us of the relevance of this approach to studying democracy.

\section{DUBIETY OF DEMOCRACY AND THE BIRTH OF "NOBODIES" \\ A Problems in the Current Discourse}

Current commentators tend to assume that democracy is a prerequisite for the protection of human rights, but democracy is not necessarily so reliable.

3 Ronald Dworkin Taking Rights Seriously (Harvard University Press, Cambridge (Mass), 1977) xi.

4 The term "Nobodies" is the author's term, and appears hereafter without quotation marks. The various ways in which states create Nobodies are analysed in Part III below. 
First of all, it is difficult to define democracy. As is well known, political scientist Robert Dahl had to invent the new concept of "polyarchy", which is forged in terms of two dimensions: public contestation and the right to participate. This was invented to avoid the confusing term "democracy". 5 Actually, democracy at present is everybody's friend: see countries with names like the Democratic People's Republic of Korea, the Socialist People's Libyan Arab Jamahiriya and the Democratic Republic of the Congo. ${ }^{6}$

While people use this term quite freely, the common denominator of the term "democracy" is merely decision by the demos, the many. Etymology tells us nothing more. Supporters for democracy would never be satisfied with an unambitious definition only related to the procedural elements. An objection might be that democracy does not just connote rule by the demos but also protection of human rights. However, while the current theory tends to regard democracy and human rights as inseparable, these two intrinsically compete with each other: the one vs the many. ${ }^{7}$ The resulting conflation of competing ideas is overlapped with the fusion of liberalism and democracy in contemporary thought. ${ }^{8}$ The wide usage of the term "democracy" can be justifiable in relation to the purpose of each writer, but such an approach hides the sharp conflict between democracy, broadly defined, and human rights. It is wrong to assume that there exists no means of reconciliation between the two. But even if one tries to conceive such a reconciliation, it is necessary to start with the recognition of the intrinsic conflict. The reason why this conflict is mentioned less by international lawyers than by domestic lawyers is that many undemocratic states do not take human rights seriously as a matter of fact. Nonetheless, this empirical tendency cannot resolve the conflict. An analytical approach is necessary for finding Nobodies who suffer from the globalising gap between human rights and democracy.

The second problem relates to the ambiguity of "international" democracy. The current discourse tends to place more importance on the internal governance of states than the question of external self-governance that was formerly emphasised. Thomas Franck, one of the leading scholars in this area, pointed to three subsets of democratic norms to assess whether an international democratic order is emerging: self-determination, freedom of expression and a right to free and open

5 Robert A Dahl Polyarchy: Participation and Opposition (Yale University Press, New Haven, 1971) ch 1.

6 North Korea was criticised as "state sponsors of terrorism" by the United States, one of the most zealous advocates for democracy. United States Department of State Country Reports on Terrorism 2005 (Publication 11324, Washington, 2006) 171-177.

7 As for this antinomy, see Philip Allott Eunomia: New Order for a New World (Oxford University Press, Oxford, 1990) 60-66. See also James Crawford "Democracy and International Law" (1993) 64 BYIL especially 115 and 132 .

8 Critical analysis is found in Susan Marks "International law, democracy and the end of history" in Gregory H Fox and Brad R Roth (eds) Democratic Governance and International Law (Cambridge University Press, Cambridge, 2000) 532-566. 
elections. ${ }^{9}$ Other than self-determination in its external aspect, these norms are concerned with the quality of countries' internal governance, irrespective of the dominant principle of non-intervention. Human rights, including freedom of expression and the right to free and open elections, have attained the status of "international concerns" since the end of the Second World War. In the 1960s, just after the end of the colonial era, on the other hand, more importance was paid to the external aspect of human rights based on national independence. Democracy in those days paid more attention to other issues such as the legitimacy of the one-country-one-vote system in the General Assembly of the United Nations (UN), the undemocratic character of the Security Council of the UN or the weighted voting systems in various international organisations. Those issues arise not in the internal sphere of states but in the international sphere between states. In discussing international democracy, therefore, a distinction should be made between "democratisation in the domestic sphere" and "democratisation between states". The latter tends to underline the importance of the state being sovereign, conflicting with the intervention the former would promote. A situation of democracy versus democracy arises and, even if one democracy tries to protect Nobodies, the cooperation of the other democracy is not assured.

A paradoxical situation emerges in the question of democratic deficit. In general, the international organisations criticised for their democratic deficit show strong support for democratic values at the same time, including the European Union, the World Bank, the International Monetary Fund, the World Trade Organisation and the UN Security Council. More important is the United States, which exerted hegemonic power after the end of the Cold War and even more problematically has done so since September 11, 2001. Like it or not, people in the world find it difficult to escape from the influence of the United States President's decisions, while they can never participate in his or her election. Academic literature has come to talk of "Hegemonic International Law", ${ }^{10}$ which promotes liberal-democratic values but operates in a way that is incompatible with them.

Thirdly, the question arises as to whether democracy is actually legitimate and justifiable, if we succeed in defining the term anyway. An approving but rather vague impression of democracy dominates the contemporary discourse, but, as is often recalled, the Nazi holocaust was the result of democratic and lawful support. History shows the problem has never disappeared. How about Yugoslavia in 1990? How about the Hamās administration in Palestine which maintains its policy of taking up arms but was born as the result of the first democratic election in the Islamic world? One may even dare to ask how we can distinguish these cases from the United States-Iraq war that is

9 Thomas Franck "Legitimacy and the Democratic Entitlement" in Gregory H Fox and Brad R Roth (eds) Democractic Governance and International Law (Cambridge University Press, Cambridge, 2000) 25-47, 52 and following.

10 Detlev F Vagts "Hegemonic International Law" (2001) 95 Am J Int'l L 843. See generally Michael Byers and Georg Nolte United States Hegemony and the Foundations of International Law (Cambridge University Press, Cambridge, 2003). 
supported by a relatively small number of political leaders in the "alliance", but not supported by either the general public in the same states nor a larger number of political leaders in other states? Democracy has been supported as opposed to absolutism in the modern age. But this just means that democracy is thought to be better than absolutism.

\section{B The Structure Producing "Nobodies": How Are They Born?}

Not only is democracy unreliable in protecting human rights, let alone the rights of Nobodies, but also it can also cause the violation of human rights. This is structurally unavoidable.

The origin of Nobodies lies in the very theory that legitimises states: social contract theory. As is well known, ${ }^{11}$ the essential elements are natural rights and a social contract to protect them, producing state power. These two elements correspond to two concepts of freedom: negative freedom and positive freedom. ${ }^{12}$ Democracy relates to the latter.

At least two questions need to be asked. One of them relates to who governs. In Hobbes's construction, power was exclusively concentrated in the Leviathan and his model is usually regarded as a form of absolutism. Rousseau forged a magical conception, "la volonté générale", distinct from "la volonté de tous", to avoid the gap between the governor and the governed. ${ }^{13}$ This is too fictitious, however. Moreover, direct democracy is impossible in the real world, so that representation is unavoidable. As a result, those who are ruled are easily turned into Nobodies. Another question arises as to the range of "every one" who forms the social contract. They are usually called "nationals". Human rights assume a universal character because of the background principle that everyone enjoys human rights just because they are human. Nonetheless, this ideal must be actualised by a specific political system, usually the "State" in social contract theory. As a result, in a specific political community, human rights, having a universal character, become "national" rights which are not universal. A discussion of democracy needs, therefore, to define the range of "demos" (or nationals). In turn, it is necessary to look at who are expelled by the demos and become Nobodies.

In the international sphere, several conceptions of the relationship between domestic and international law are possible: (1) the dualistic coexistence model in which law is divided into the international level and the domestic level and the external interests of states are limited to their mutual co-existence; (2) the dualistic cooperation model in which law is divided into two and states aim for international cooperation, with two levels of social contracts, as argued in John Rawls' The Law of

11 Thomas Hobbes (Richard Tuck ed) Leviathan (Cambridge University Press, Cambridge, 1996) ch 14.

12 Isaiah Berlin Two Concepts of Liberty (Clarendon Press, Oxford, 1958).

13 Jean-Jacques Rousseau Contrat social in C E Vaughan (ed) The Political Writings of Jean-Jacques Rousseau (Vol II, Basil Blackwell, Oxford, 1962) book 2, ch 3. 
Peoples; ${ }^{14}$ and (3) the monistic model in which law applies globally and only one global social contract is made.

No detailed explanation can be made here, ${ }^{15}$ but it should be mentioned that globalising social contract theory does not diminish its difficulties; in fact it does the reverse. One of the problems is its presupposition of abstract individuals. Hobbes and the theorists succeeding him, and especially Rawls, prepared a theoretical device, "a veil of ignorance", which eliminates individuals' features such as nationality and social status. However, international law must deal with pluralistic societies where individuals can have different ethnicities and nationalities within different states. The number of potential combinations of features is immeasurable.

The dualistic models presuppose that nation and state bear a one-to-one relation with each other, but no such perfect nation-state exists. Nothing more than a rough relationship can be found between the nation, originated in the birth of its nationals, and the state, consisting of a unit of administration of a certain area. For example, even in Japan - known as a highly homogeneous society - there are about 24,000 Ainu people who fall into the definition of "minorities" prescribed by Article 27 of the ICCPR. ${ }^{16}$ Residents from South and North Korea and the descendants of the untouchables are also considered separate. The abstract character of social contract theory, and the nation-state system, can, however, make these problems invisible.

Another problem with the dualistic constructions is that the status of human rights remains discretionary in the international sphere. Some commentators argue that the social contract within each country suffices for human rights protection. Indeed, for example, it is difficult to say that before 1992 the United States regarded human rights as less important than other states, even though it was only in that year that it signed up to the ICCPR. However national protection may limit its scope to the rights of nationals and, more importantly, tends to think little of minorities or other individuals who are somehow "outsiders" within states. In such cases, international protection is more than a mere luxury.

The monistic conception, designed to overcome the difficulties of the dualistic conception, seems fashionable today. Nonetheless it is doubtful that scholars and practitioners would regard it as desirable after much thought is given to its real application. If the monistic approach is applied strictly, the individuals of China, not the country itself, would have one-fifth of the votes in the world, followed by the populations of India and the United States. The remaining people in the world would likely be in favour of a form of democracy that was confined to the relations between states in order to prevent decision-making from being dominated by the larger, and therefore more influential, states.

14 John Rawls The Law of Peoples (Harvard University Press, Cambridge (Mass), 1999).

15 For detail see Koji Teraya Kokusaijinken no Itsudatsufukanōsei [Non-derogability of International Human Rights] (in Japanese, Yuhikaku, Tokyo, 2003) 325-358.

16 International Covenant on Civil and Political Rights (16 December 1966) 999 UNTS 171. 
In a word, one seems to use democratic labels at one's convenience in each context. Additionally, international democracy does not always promote human rights and human rights do not always require international democracy.

The abstract character of the social contract theory stands out more in the monistic construction. In fact, this cosmopolitan view owes its charm to its fictitious conception. The more idealised the theory, the more attractive it appears. Supporters envisage a better world, portraying Kant as the great father. However, he himself expressed a caveat in his work as early as 1795 . He was opposed to an amalgamation of separate nations under a single power, writing that "weil die Gesetze mit dem vergrößerten Umfange der Regierung immer mehr an ihrem Nachdruck einbüßen, und ein seelenloser Depotism, nachdem er die Keime des Guten ausgerottet hat, zuletzt doch in Anarchie verfällt." ${ }^{17}$ Are we confident in saying that democratic support today does not fall into "ein seelenloser Depotism" (a soulless despotism)? Although the monistic conception is preferable to a dualistic conception from the perspective of Nobodies, this reminds us of criticism directed at liberal democracy, especially when we are faced with United States unilateralism. At a glance, cosmopolitanism and United States hegemony share a similar structure. As already mentioned, the empire of liberal-democracy is yet to recognise the inconsistency in its own thought.

The last question that arises involves representation. Practically, in spite of its charm, the monistic idea has to take actual form in the real world and the nation-state is the most fundamental representative political unit in the world. Thus, the monistic construction has to tackle the same problem as the dualistic constructions do, even if it tries to provide a theoretical foundation for the protection of all Nobodies in the world.

\section{HOW THE DEMOS EXPELS NOBODIES (1): EXPULSION AND THE NATION-STATE}

The birth of a nation-state is accompanied by the creation of Nobodies. The following section covers the different ways in which this system reduces individuals to the status of Nobodies.

\section{A Those Outside Their Own Nation-State}

Social contracts are made within a specific society. The relationship formed between citizens and the state has no relevance to other societies, giving no suggestion as to how those societies should treat the citizens of other societies. Government "of the people, by the people, and for the people" does not necessarily take care of other "peoples". The founders of social contract theory said little on external matters. Hobbes described the relationship with those outside civil societies as a "state of war" and Rousseau, although recognising the question's importance, just mentioned it as a remaining

17 Immanuel Kant Zum Ewigen Frieden (1795). In translation, "For the laws progressively lose their impact as the government increases its range, and a soulless despotism, after crushing the germs of goodness, will finally lapse into anarchy" (in Hans Siegbert Reiss (ed) Political Writing (Cambridge University Press, Cambridge, 1970) 113. 
question in the last chapter of Contrat social. ${ }^{18}$ His patriotism can be open to all human beings and, in this sense, there exists the possibility of the globalisation of social contract. However, this was not adopted by his successors. Marxism produced a huge movement which claimed the solidarity of the lower classes beyond borders, but ultimately nationalism prevailed and Marxism itself turned out to produce totalitarian states.

Democracy strengthens the expulsive function of nation-states. Democracy and patriotism are separable logically, yet both tend to presuppose the unity of their political community. When states play a zero-sum diplomatic game, such as in war, patriotism tends to express itself in an aggressive attitude. Emphasising the unity of nation-states leads members to regard helping other nationals as wrong. From the point of view of traditional international law, there is no obligation to assist other states. Although the UN Charter prescribes various obligations to cooperate, states' discretion remains broad and no specified obligations of humanitarian intervention, interference or assistance are enforced. Leaders can ignore Nobodies suffering from difficulties such as war and poverty for legitimate reasons supported by the concept of national democracy.

More seriously, history tells us that democracy in one state can hinder democracy in other states within the framework. Although the Northern Hemisphere-Southern Hemisphere problem originated in the 16th century, the gap has become clearer in the last century. Developed states usually adopt imperial policies. While fostering democracy in their own countries through the wealth gained by exploiting undeveloped areas, developed states force the undeveloped to face enormous difficulty in changing their political system because the ruling class is supported by this democratic empire. ${ }^{19}$ The pride of supporters of democracy, such as admirers of democratic peace theory, would be more damaged if they turned their eyes not only to the misery of wars between democratic states and undemocratic states and between undemocratic states themselves and but also to the above hidden structure that serves to keep undeveloped states in such a situation. It is an exaggeration to say that democratic states always do so, but it must be recognised that democracy can develop in a way that sacrifices other states' democratisation, just as the Athenian democracy was preserved by the slavery system.

\section{B The Cause of Quasi-Nationals: the Nationality Problem}

Nationality can be decisive, because one of the easiest ways to make people Nobodies is to not grant them or deprive them of nationality. One could argue that the right to nationality is firmly established, as prescribed by Article 15 of Universal Declaration of Human Rights, Article 24(3) of the ICCPR and Article 7(1) of Convention on the Rights of the Child. However, the right to nationality cannot be realised without a state recognising it. Nationality bases the protection of

18 Rousseau, above n 13, book 4, ch 9.

19 Y Sakamoto Sekaichitsuzyo to Shiminshakai [World Order and Civil Society] (in Japanese, Iwanamishoten, Tokyo, 2005) 215-217. 
human rights on the condition that they are realised mainly though states' obligations and the rights to nationality depend on states' discretion. In the famous Advisory Opinion on the Tunis and Morocco case, the Permanent Court of International Justice noted that: "The question whether a certain matter is or is not solely within the jurisdiction of a State is an essentially relative question; it depends upon the development of international relations. Thus, in the present state of international law, questions of nationality are, in the opinion of the Court, in principle within this reserved domain". ${ }^{20}$ In essence, nothing has changed to this day. Additionally, there is no binding instrument that makes human rights as real as national rights throughout the world. Even the treaties concerning nationality can be derogated from so that they do not furnish a firm basis. A fragile basis of nationality is the ultimate cause of quasi-nationals.

\section{Quasi-Nationals 1: Stateless Persons and Refugees}

Stateless persons and refugees are different from other Nobodies in that they are related to two states: their home states and the receiving state. For stateless persons, the home states are just imaginary.

Social contract theory may have difficulty in explaining the rights of stateless persons and refugees. Thrown into a specific society at their birth, ordinary individuals have no experience to make a real social contract. On the other hand, stateless persons hold two choices: making a real social contract with others in a similar situation or entering into a society that already has a legal community. The former, establishing a new state, is too difficult for individuals in reality. Thus, the latter, gaining admission to stay in a state, usually forms the first step in acquiring nationality. This is the equivalent of forming a social contract.

Refugees' special hardship is a result of states, despite the fact they are supposed to protect them through the social contract, turning out to be enemies or indifferent "third parties" infringing their rights by action or inaction. This was not unanticipated, however. Critics have pointed out this danger, especially in the Hobbesian conception in which the tyrannical Leviathan has absolute power. Even more moderate constructions cannot go on to deny states' right to punish criminals. Because states hold the right to decide who criminals are, infringing rights and punishment of criminals unavoidably appear the same. International law tries to mitigate the severity by introducing norms such as the non-extradition of political offenders, but the main framework remains unchanged.

Louis Henkin argues that individuals have the right to terminate their social contract by leaving their society, but, as he writes, they do so under the condition that they have neither the right to the nationality of their choice nor the right to live in a country of their choice: "The right to leave one's country, then, even for one who must leave it because of persecution, is only half a right, or less". ${ }^{21}$

20 Nationality Decrees Issued in Tunis and Morocco (French Zone) on November 8th, 1921 (Advisory Opinion) [1923] PCIJ (Series B, no 4) 1, 24.

21 Louis Henkin The Age of Rights (Columbia University Press, New York, 1990) 48. 
Whether stateless persons and refugees are admitted to states is based on states' discretion. The 1951 Convention relating to the Status of Refugees has its own definition in Article $1,{ }^{22}$ but owing to the lack of provisions on the procedure used to acknowledge refugees, each state assumes that they have the right to determine admission in their own manner.

Democratic states may tend to avoid forcing their nationals to flee across borders, but democracy is no guarantee in the case of accepting refugees. Refugees usually require more state expenditure and, naturally, states hesitate to accept them or, at least, select them to protect their national interest. If a generous attitude to refugees causes more difficulty for the lower classes in the accepting society and democracy aims at more participation in national decision, then the ideal democracy accepts fewer refugees. Most democratic states concede that the international community, so-called, should accept more refugees, but no such concrete "international community" exists. Free riding is justified if the leaders seek to maximise their national interest. ${ }^{23}$ In a word, decision by the many with no limitation can fall into unrestrained democratic egoism.

Exceptional conditions, such as in the United States, prevail when the accepting state itself consists of various immigrants and its history is closely connected to this. Nonetheless, this does not mean that former immigrants welcome the newcomers, instead valuing their vested interests over the national tradition.

The nation-state system itself creates the above difficulty. Sticking to the framework of the system tends to focus the problems solely on the entry of refugees, but treating them individually in each state has its limit. The problem has its roots so deep in the international structure that we need to look beyond that structure to find more comprehensive perspectives.

An important related issue is that of female stateless persons and refugees. They are exposed to more dangers than males. ${ }^{24}$ This suggests that there is some sort of hierarchy in Nobodies.

22 Convention relating to the Status of Refugees (28 July 1951) 189 UNTS 150.

23 According to the United Nations High Commissioner for Refugees (UNHCR), the "total population of concern" to them amounted to 19.2 million by the end of 2004 . Only 15 countries received only almost thirty thousand refugees resettled under the auspices of the UNHCR. The top three are the United States $(63 \%)$, Australia (19\%) and Canada (13\%). UNHCR "2004 Global Refugee Trends" www.unhcr.org (accessed 31 May 2006).

24 This paper does not explore this issue in detail, but it has been discussed within more comprehensive framework of feminism. See, for example International Law Association Final Report on Women's Equality and Nationality in International Law (Report of the Sixty-Ninth Conference, The International Law Association, London, 2000). 


\section{Quasi-Nationals 2: Foreigners}

Foreigners' rights are also based on fragile principles. In Japan, the McLean case, ${ }^{25}$ in which the appellant United States national was refused an extension of stay in Japan, has long been the precedent, providing the basic rule as to the rights to be accorded to foreigners. In its opinion, the Supreme Court noted that "[w]e think that the guarantees of fundamental human rights contained in Chapter Three of the Constitution, with the exception of those rights which by their nature must be limited to Japanese, apply equally to foreigners staying within our country. ... However, ... permission for aliens to stay within our country constitutionally are not guaranteed the right to stay in Japan or to seek continuation of their stay. ... Consequently, it is proper to interpret the constitutional guarantee of fundamental human rights to aliens as being given within the immigration system described above."26 This shows the difficulty of the problem. In this construction, human rights, in this context the right to participate in politics, is only possible at the states' discretion. Again, this does not really protect human rights, even if we accept that we cannot admit the unlimited entry of persons at their own will.

Democracy seems to treat foreigners no better than stateless persons and refugees. Reciprocity, regarded as a central element of the basis of obligations, ${ }^{27}$ assures that one state's interest leads to that of the other. Democracy on both sides triggers this mechanism to achieve "the greatest happiness of the greatest number". It works, however, only on the condition that these two states share similar values and interests. The wealthy states find a bilateral interest in each other. How are wealthy states going to be interested in poor states which have neither natural resources nor minimum political stability? Forgotten states such as Afghanistan and Somalia only attract attention when the atrocious situations begin sowing the seeds of crime all over the world.

\section{E Quasi-Nationals 3: Minorities and Indigenous Peoples}

The lack of nationality is not the only element that can make individuals Nobodies. Minorities and, more distinctively, indigenous peoples fall into such a category.

It may sound ironic to argue that the normative power of social contract lies in its imaginary character. As if made in time immemorial, a social contract gives nationals the impression that there would be a non-derogable constitution and that nationals would be united. The lack of proof of this is not always seen as a problem. In the case of indigenous people, however, the existence or non-existence of the social contract has been revealed as a historical fact. If we investigate the

25 McLean's Case (1978) 903 Hanrei Jihō 3 The facts and an extract from the judgment can be read in English in (1979-80) 23 Japanese Annual of International Law 176-184.

26 Ibid

27 Rosalyn Higgins Problems and Process: International Law and How We Use it (Clarendon Press, Oxford, 1994) 16. 
history of the Ainu in Japan to find the contract, for example, we find that there is none. Even if something is found, such "contracts" turn out to be invalid by the lack of sincere will, according to our general principles of "civilised" nations. The imagined social contract forces them to become members of the community and the mark of nationality is not sincere but a sham. In Japan, it was in the Nibutani Dam case ${ }^{28}$ that the Court concluded the Ainu are an indigenous people for the first time, more than a century after their "integration". The Ainu people were invisible up until that day and their rights are still vague. ${ }^{29}$

In the context of minorities, the demos, literally the opposite of the minority, play a social function to put them in an inferior position. A delicate problem turns up with indigenous peoples, a specific category of minorities: the right to land. If the indigenous people were conquered, there seems no legitimate reason not to return the right to land to them. The Court in the above case does not come to a clear conclusion on this. But, in the end, one has to conclude that power prevails over justice. Useful reference may be found in the fact that the formerly colonised states claiming the right of peoples in their independence struggle had to claim the principle of uti possidetis after they were decolonised with the border unchanged. Claiming the right to land, whether under the heading of the right of people or the right of indigenous people, would lead to unlimited division of states, because lands are one of the main components of modern states and areas of ethnic distribution lead to a complex mosaic.

\section{F War Victims in the Reconstruction of Nation-States}

All the above social contracts are thought to be made in the past. In the modern context, peace agreements in contemporary peace making processes provide the closest real parallel to this theoretical product. In failed states such as the former Yugoslavia, Afghanistan and East Timor, peace agreements play the role of social contracts, giving individuals the status of new nationals. However, the reconstruction of new democratic nation-states can also produce Nobodies in rather different forms than other cases. A truth commission is one of the forms among them. It is said to be more suitable than a criminal court for nation-building in some cases. While punishing criminals is necessary or effective in some cases, such as the Nuremberg Trials and the Tokyo Trials, it is also true that other cases such as Rwanda can do without retribution, especially when much of the population engaged in atrocious deeds. It means, however, that the victims' rights are sacrificed for national stability and they become Nobodies in the name of justice.

28 Nibutani Dam (1997) 1598 Hanrei Jihō 33 (Sapporo District Court). The facts and an extract from the judgment can be read in English in (1998) 41 Japanese Annual of International Law 92-95.

29 Although in a different context, the Mabo cases and the subsequent legislation in Australia are more advanced. See for example Mabo v Queensland (No 1) (1988) 83 ALR 14; Mabo v Queensland (No 2) 107 ALR 1 . 
In general, reconstructions of democratic nation-states tend to entail sacrificing other values. Renunciation of individuals' rights to war compensation is a familiar feature of peace treaties between different states. The issue often arises again years later, however, even if the nation-states seem firmly established. An example is the revival of war compensation trials since the 1990s against Japan by Chinese and Korean people. ${ }^{30}$ Democratisation in Korea in 1980 s is one of the reasons that victims' trials have become possible. Democracy has the potential to save Nobodies. At the same time, this situation shows that democracy does not assure a solution, especially if the Japanese demos, the victimisers, do not have the will to solve the problem.

\section{HOW THE DEMOS EXPELS NOBODIES (2): EXPULSION AND LAW}

Law, as well as states, promotes the expulsion discussed above, because law is usually made by the majority in democratic societies. If law is understood exclusively as an expression of consensualism, or if law is just an arithmetic sum of peoples' will, then it is in turn just an expression of the majority's will.

Unlike other political communities, modern states have territory, and accordingly their expulsion is physical. On the other hand, expulsion by law is metaphysical, forming an invisible wall.

\section{A Expulsion in the Formation of Law}

The expulsion discussed so far takes place in the process of state-building. Because the state is an actualisation of law, ${ }^{31}$ state law can encourage the majority to expel Nobodies in "their" territory.

As well as state law, international law can also be complicit in the expulsion of Nobodies. In democratic states, concluding a treaty, especially when it affects the relevant nationals, must typically be considered not only in the executive branch but also in the parliament composed of national delegates. Another main form of international law is customary international law, generally understood to require state practice and opinio juris. The formation of customary international law is more vague and more influenced by large powers, whose practices carry more weight. In the modern context, it is submitted that these "powers" should be understood as including not just states but also other entities such as multinational companies and NGOs. The opinio juris of democratic states is also that of the demos. In identifying the opinio juris, the power to transmit information has much relevance. Indeed although NGOs have undoubtedly made considerable contributions in the human rights field, it is difficult to deny that their global legitimacy is questioned by the fact that most NGOs originate in the United States and European States. ${ }^{32}$ The de facto language is English, making other

30 For example, on "comfort women" (1998) 1642 Hanrei Jihō 24 (Yamaguchi District Court) and (2001) 1759 Hanrei Jihō 42 (Hiroshima High Court). The type of war compensation is different from each other.

31 See Hans Kelsen General Theory of Norms (trans Michael Hartney, Clarendon Press, Oxford, 1991) 144-148.

32 Yasuaki Onuma Jinken, Kokka, Bunmei [Human Rights, States, Civilisations] (in Japansese, Chikumashobō, Tokyo, 1998); especially chap 4; Yasuaki Onuma "A Transcivilizational Perspective on Global Legal Order in the Twenty-first Century: A Way to Overcome West-centric and Judiciary-centric Deficits in International 
languages nearly "nothing". Considering that many states still have difficulty in providing their nationals with the opportunity of learning even their mother tongue, the power of Nobodies to influence the formation of customary international law seems remote indeed.

International law, whether in the form of treaty or custom, is expected to provide protection to Nobodies. If formed democratically without any care being given to Nobodies, however, international law can deteriorate into an apology for democratic egoism in state practice.

\section{B Expulsion by Criminalisation}

\section{$1 \quad$ Illegality and outlawry}

It is in making people outlaws that the law shows its expulsive character most clearly. The most noticeable example is the United States policies in the "Global War on Terror". The day after September 11, President George W Bush declared that "The deliberate and deadly attacks which were carried out yesterday against our country were more than acts of terror. They were acts of war." ${ }^{13}$ Generally it has not been objectively decided whether the current situation is one of war or not. While the acts of September 11 are illegal acts within the framework of relevant treaties on terrorism, they became acts of war just because President Bush declared them to be so. This is a justifiable declaration in terms of the grave injury people suffered, but the identification of a situation as war should be done consistently. The problem is, as critics have commented, that the United States does not treat the terrorists as prisoners of war in spite of their identification as being at war with America. Terrorists become neither criminals nor combatants in terms of humanitarian law, but take some other existence under the name of "enemy combatants". In a word, they are expelled outside of international law. ${ }^{34}$ The base at Guantanamo Bay is an example. In these situations, we see the emergence of a third state, neither a state of war nor a state of peace, but more like a state that is sui generis and which the United States claims at its own convenience. These "enemy combatants" are Nobodies in the sense that neither national law nor international law recognises them.

One could argue that terrorists are different from the Nobodies already mentioned, because the latter deserve to be saved from their situation. They overlap, however. Hamās, supported by Palestinian refugees, is one of the obvious examples. Osama Bin Laden, although he himself is from a rich family in Saudi Arabia, recruited terrorists from refugees in failed states. Some go so far as to argue that September 11 is one of the consequences of the North-South problem. Needless to say,

Legal Thoughts" in Ronald St J Macdonald and Douglas M Johnston (eds) Towards World Constitutionalism: Issues in the Legal Ordering of the World Community (Martinus Nijhoff Publishers, Leiden, 2005) 86-189.

33 George W Bush "Remarks by the President (September 12 2001) Press Release available at www.whitehouse.gov (accessed 31 October 2006).

34 The US Supreme Court, at last, judged the violations of Common Article 3 of the Third Geneva Convention in Hamdan v Rumsfeld, Secretary of Defense (2006) 126 S Ct 2749. 
not all terrorists were miserable refugees in the past and, even if they were, the acts must be evaluated separately. The above tendency has to be mentioned, however.

The resemblance between the above Nobodies and terrorists is not just empirical. What should be mentioned is more than just the fact that counter-terrorism laws make rights of movement difficult to exercise, especially beyond borders, and that Arabs are treated unfairly in passport control and other situations. More important is the theoretical parallel between the two, in that they are expelled by the demos to the outer world.

Stateless persons, by definition, stand outside of national laws. So do refugees. As for foreigners generally, an attempt was made at the international law level to deal with their human rights in the Declaration on the Human Rights of Individuals Who are not Nationals of the Country in Which They Live. ${ }^{35}$ Economic and social rights are assured only to "[a]liens lawfully residing in the territory of a State" (article 8, emphasis added), while no limitation exists in civil and political rights (article 5). In terms of the promotion of Nobodies' rights, two evaluations are possible. One is to praise the Declaration in that civil and political rights are interpreted to be provided even for unlawful foreign residents. Lack of the term "lawfully" must be intentional in relation to Article 8 . The other evaluation is concerned with on economic and social rights. While it could be unreasonable to give such rights to unlawfully-resident foreigners, the dichotomy presupposed by the Declaration cannot be sustainable from the perspective of the dominant human rights theory of emphasising the indivisibility of human rights. ${ }^{36}$ Japanese case law basically follows the approach of the Declaration. ${ }^{37}$ The issue is contentious, however, as we can see in the large demonstrations in the United States against illegal immigrant problems in 2006. Is it really safe to argue that unlawful foreigners cannot enjoy economic and social rights?

While one can claim vociferously that human beings are equal, it is not always quite certain whether outlawed persons should be treated in the same way. In fact, they are expelled in order to treat them in a different manner. Unlawful combatants are a perfect example.

Two types of criminals can be created here. One is a person who has acted illegally, contrary to law but who is still recognised as being within the law and therefore enjoys human rights. The other

35 Declaration on Human Rights of Individuals Who are not Nationals of the Country in Which They Live (13 December 1985) A/RES/40/144.

36 Jack Donnelly Universal Human Rights in Theory and Practice (Cornell University Press, Ithaca, 1989) ch 2; Patrice Meyer-Bisch Le corps des droits de l'homme (Editions Universitaires Fribourg Suisse, Imprimerie Saint-Paul Fribourg Suisse, 1992) 121-229; "Symposium: The Implementation of the International Covenant on Economic, Social and Cultural Rights" (1987) 9 HRQ 121.

37 (1997) 1611 Hanrei Jihō 56 (Tokyo High Court). 
is an outlaw, deprived of the benefit of the law. ${ }^{38}$ Outlawry as a legal term means a process in old English law, which had formally ceased to exist by $1938 .{ }^{39}$ It is said that the United States law never recognised it, but the labelling of "enemy combatants" seems the same kind of the process. In the Hamdi case, ${ }^{40}$ although the Supreme Court concluded that Hamdi had a meaningful opportunity to contest the factual basis for the detention before a neutral decision-maker, this was only possible because he had United States nationality. In addition, after the negotiations between his lawyers and the government, Hamdi was permitted to go back to Saudi Arabia under the condition that he lost his nationality. One can argue that this is a revival of outlawry.

\section{Democratic Expulsion}

Democracy is sometimes bitter towards outsiders. This becomes clear when security, the core raison d'être of states, is at issue, because it is evaluated by system of negative assessment, recording the breaches of and threats to security. Among crimes, this is most obviously related to terrorism. In spite of frequent references to the vagueness of the definition of terrorism, the act to be punished is clearly defined in the relevant treaties such as article 2 of the International Convention for the Suppression of Terrorist Bombings. ${ }^{41}$

Nevertheless, the impact of terrorism is omnipresent, with uncertainty prevailing in that people do not know when and how terrorism might occur. They just imagine and fear it, although, in fact, motor traffic in our daily life causes more death. The demos has lawfully such a "freedom" to fear. ${ }^{42}$ Terror is the very purpose of terrorism. It does not matter who will actually commit the crime. Depersonalised fear, with excessive reactions, would encourage the creation of a surveillance state with perpetual measures to infringe human rights. This is the ultimate success of terrorism. Accepted by the many as a vital value, security is thought to be achieved by the elimination of dangerous elements: as many as possible and as soon as possible before the danger manifests itself. Possible dangers have to be found by imagination. One of the consequences is thus purifying the community to eliminate the existence of a possible enemy as far as possible. Purifying members is unavoidable tendency of democracy and there is no limitation inherent in the process.

38 This feature corresponds to "Homo Sacer" argued by Italian philosopher Giorgio Agamben. See Giorgio Agamben Homo Sacer: Il potere sovrano e la nuda via (Piccola Biblioteca Einaudi, Torino, 1995), especially 139-149.

39 See, for example, G Jacob, enlarged and improved by T E Tomlins The Law-Dictionary (Vol II, 1797).

40 Hamdiv Rumsfeld, Secretary of Defense (2004) 542 US 507.

41 International Convention for the Suppression of Terrorist Bombings UNGA Resolution 164 (15 December 1997) A/52/164; (1998) 37 ILM 249.

42 Anthony Carty "The terrors of freedom: the sovereignty of states and the freedom to fear" in John Strawson Law after Ground Zero (Glasshouse Press, Sydney, 2002). 
In a democracy, the decision by the many is regarded as the decision of community as a whole, as if everyone had given their consent. If democratic logic is applied limitlessly, law becomes just an instrument for the demos to expel others.

Democracy praises the many, but it is not always true that the many is right. Punishment of criminals is the same as a human rights violation from the viewpoint of the person being punished. These two cannot be differentiated objectively. States would be the robbers and killers without the lens of law. History shows that the many can violate the rights of minorities and vice versa. Rightness has no intrinsic relevance to the size of community. In the situation where two communities of different sizes conflict with each other, what can be claimed (at least) is that if one does not conform to the common standard validating both sides - the law - then they become outlaws themselves. Products by persons within law are lawful by the connection of competence, while it is only outlaws that produce the outlaws.

The problem is not solely attributed to the policies of the George W Bush administration. Democracy can outlaw itself.

\section{Recognition by Committing Crime}

A paradox can be found at a glance in the fact that committing crime, contrary to the above, provides a route to becoming a member of the community. In doing so, the ignored win recognition from the many, "gaining" human rights. Impressively, Hanna Arendt described stateless persons and minorities in the first half of the twentieth century thus: "For then a criminal offense becomes the best opportunity to regain some kind of human equality, even if it be as a recognized exception to the norm. The one important fact is that this exception is provided for by law. As a criminal even a stateless person will not be treated worse than another criminal, that is, he will be treated like everybody else." 43 What Arendt shows is explained by the schema mentioned above, which separates three states - peace, war and something else - and differentiates two criminals - illegal and outlaw. Nobodies can aim to "raise" their status from outlaws to criminals.

Arendt's observation was made before the development of international human rights law, yet the situation remains basically unchanged. As mentioned earlier, human rights treaties provide many procedures for observance, but those are insufficient and the right to nationality, the right to belong to a state - which is the most reliable institution for human rights protection - is not recognised in a fully-fledged manner. The problem Arendt confronted seems to continue, but in more serious way. She mentioned stateless persons and minorities, but those categories of persons are expanded to what this paper has called Nobodies, embedded deep in the structure that produces them. Her mention of crime covers burglary at most. In the age of globalisation, however, Nobodies can go so far as to commit crimes that paralyse the economic centre of superpowers.

43 Hannah Arendt The Origins of Totalitarianism (Harcourt, San Diego, 1948) 286. 
Everyone is, as frequently mentioned, vulnerable to becoming a victim in the global risk society. ${ }^{44}$ On the other hand, some are destined to be victimisers regardless their will, such as child soldiers. They can enter into the world community by their "revenge". This also happens on a larger scale. "The forgotten lands" such as Afghanistan and Somalia come to the forefront of globalisation issues by being a hotbed of crime whose influence extends all over the world. This is similar to states that gain a little recognition and want more by having nuclear bombs. Certainly, not all desires for recognition are justifiable. Yet the vicious cycle of ignorance and revenge should be terminated. For that, it is necessary to make Nobodies visible at least through the lens of law.

\section{CONCLUDING REMARKS}

In theory, a reconceptualisation of state and law is one of the most important prerequisites to responding to the globalising tension between human rights and democracy, which would lead to reform of the traditional concept of international law. ${ }^{45}$ Before such a fully-fledged study can be undertaken, this paper confines its aims to reconsidering the dominant opinion that democracy is good however it is defined. Going against this common understanding, democracy is not always supportive and is even hostile to human rights protection in some cases. Such cases result from the very nature of democracy. Nobodies, an ultimate expression of a minority, can be produced by the nation-state system and law within a democratic system. Unfortunately, therefore, there is a risk that blind efforts to reduce the "democratic deficit" could result in aggravating the violation of the rights of Nobodies.

Democracy itself is not an ultimate value but rather a means to such values and can be evaluated in terms of its contribution to them. In this sense, democracy is not a solution but a question, and will remain so.

44 Ulrich Beck World Risk Society (Polity Press, Cambridge, 1999).

45 See generally Mireille Delmas-Marty Trois defies pour un droit mondial (Seuil, Paris, 1998); Philip Allot The Health of Nations (Cambridge University Press, Cambridge, 2002) 289-315. 